\title{
Effect of Parental Influence on Students' Personality and Academic Achievement at Secondary School Level
}

\author{
Summera Batool ${ }^{1}$ \\ Dr. Shamsa Aziz ${ }^{2}$
}

\begin{abstract}
This study tried to investigate the effect of parental influence on students' personality and academic achievement at secondary school level in Islamabad. The objectives of the study were; to measure parental influence, student's personality and academic achievement, to determine the effect of parental influence on students' personality, to determine the effect of parental influence on students' academic achievement, to find out the gender wise difference of parental influence on students, to find out the gender wise difference in students' academic achievement and to find out the gender wise difference in students' personality. The study was causal comparative in nature. Proportionate stratified sampling technique was used for sample selection. The sample of the study consisted upon 400 students studying in class $10^{\text {th }}$ in public sector schools in Islamabad. Two research instruments were used in this research. For measuring parental influence, five-point rating scale was developed by researcher. For Assessment of personality Big Five Inventory was modified (John \& Srivastava, 1999). Students' academic achievement was measured by their marks which they obtained in class $9^{\text {th }}$ annual examination. For data analysis, mean score, one-way ANOVA and t-test was used. It was found that parental influence had significant (negative) effect on students' academic achievement, partial effect on five factors of students' personality, and no significant effect on students' total personality. There was a significant gender wise difference in students' academic achievement, no significant gender wise difference of parental influence was found on students, and there was no significant gender wise difference in student's personality.
\end{abstract}

Keywords: Parental Influence, Personality, Academic Achievement, Secondary School level

\footnotetext{
${ }^{1}$ MS Scholar, Department of Education, International Islamic University Islamabad, Email: summerakhan178@gmail.com

${ }^{2}$ Chairperson/Associate Professor, Department of Education, International Islamic University Islamabad, Email: shamsa.aziz@iiu.edu.pk
} 


\section{Introduction}

There are various factors that affect students' academic achievement for example, parent's educational background, family income, school environment, self-motivation of students and so on. Among these factors, one of the important factor is parental influence or parental pressure. All parents always think and consider best options for their children; they dream about top universities, they want productive careers for their children, for competing within a global and competitive economy. Students should perform well during their school life to meet these expectations. Most parents force their adolescents to achieve high grades at every cost. Parents' pressure is a concept which is widely used, but rarely well defined. It refers to the effects that parental behaviors have on children's performance. It refers to how parents influence their child's behavior, whether it's intentional or not. The term has a somewhat negative connotation, which may lead to conclude that it is an undesired effect of parental behavior on child performance; however, parental pressure may also be and lead to desired effects on child performance (Watson \& Skinner, 2012).

When parents pressurize their children to succeed at any cost is called parental influence or parents' pressure. This is normally for being topper in the selected area. Any family member can put this pressure to achieve perfect marks and grades and to fully succeed in academics. Parents wish that their children should remain on the top position in every field including study, games, fine arts, songs, in school and in social life, however it is impossible. Pleasure which is received by child's favorite work matters a lot. Increased parental pressure for higher grades can lead students towards stress which can affect student's academic performance. According to Shazia (2014), achievement indicates the amount of success achieved in special tasks related with school, particularly student's progress towards successful course and program completion. So, "academic achievement" is the acquired skill to complete tasks related to school. Generally, it indicates essential learning that students have achieved.

A person's personality is the combination of his or her unique and consistent thoughts, feelings, needs, motives, values, attitudes and behaviors. It eliminates race, gender and physical charm. Personality describes a person's total ways of reacting and interacting with other people. Personality is a relatively stable set of characteristics that influence a person's behavior. It involves a continuous process that is dependent upon various internal and external influences; it includes hereditary and innate tendencies, social experience and changing environmental conditions (Hiriyappa, 2012).

In case of increased parental influence self-esteem issues and confidence problems can arise specifically, when a child is passing through the crucial stage 
of teenage. He might start feeling sad and lonely, which could result in lack of satisfaction as an adult. If parental influence exceeds from a limit, a child can start questioning his own intelligence and abilities. It can further affect his learning and growth. In this scenario, parents' influence becomes a big issue for students specifically, because they are required to do hard work, for turning their parents dreams into reality and to recognize their personal identity beside their parents' demands. Academic achievement and students' personality are equally important because students' complete development is the major aim of schooling, therefore, considering the factors which can have an effect on students' personality and academic achievement is essential, Thus, the researcher tried to investigate the effect of parents' influence on students' personality and academic achievement.

\subsection{Objectives of the Study}

1. To measure parental influence, students' personality and academic achievement at secondary level.

2. To determine the effect of parental influence on students "personality at secondary level.

3. To determine the effect of parental influence on students' academic achievement at secondary level.

4. To find out the gender wise difference of parental influence on students at secondary level.

5. To find out the gender wise difference in students' academic achievement at secondary level.

6. To find out the gender wise difference in students' personality at secondary level.

\subsection{Hypotheses}

$\mathrm{H}_{\mathrm{o} 1}$ : There is no significant difference between the students' personality having high, low and moderate parental influence.

$\mathrm{H}_{02}$ : There is no significant difference between the extraversion factor of students' personality having high, low and moderate parental influence.

$\mathrm{H}_{03}$ : There is no significant difference between the agreeableness factor of students' personality having high, low and moderate parental influence.

$\mathrm{H}_{04}$ : There is no significant difference between the conscientiousness factor of students' personality having high, low and moderate parental influence.

$\mathrm{H}_{\mathrm{o} 5}$ : There is no significant difference between the neuroticism factor of students' personality having high, low and moderate parental influence.

$\mathrm{H}_{06}$ : There is no significant difference between the openness factor of students' personality having high, low and moderate parental influence. 
$\mathrm{H}_{07}$ : There is no significant difference between students' academic achievement having high, low and moderate parental influence.

$\mathrm{H}_{\mathrm{o} 8}$ : There is no significant difference between male and female students regarding parental influence.

$\mathrm{H}_{09}$ : There is no significant difference between male and female students' academic achievement.

$\mathrm{H}_{\mathrm{o} 10}$ : There is no significant difference between male and female students' personality.

\subsection{Significance of the Study}

The present study may be helpful for parents to improve the personality development and the academic achievement of their children by managing parental influence. It can guide parents about their role in improvement of their children's academic performance. The present study may guide institutions to value the importance of parent teacher meetings and to arrange such meetings regularly.

\subsection{Delimitations of the Study}

The present research was delimited to the $10^{\text {th }}$ grade students of public sector schools of Islamabad.

\section{Review of Literature}

Quach et al. (2013) studied parental warmth and academic pressure's effect on anxiety and depression symptoms in Chinese adolescents. They reported that there was a positive association between parental academic pressure and adolescents' depression and anxiety. Irfan \& Hussain (2014) researched the reasons of parental pressure on students to achieve higher marks and students' levels of anxiety and stress in their study "parental pressure on student's attainment of high grades in Karachi based universities". They concluded that males were facing more pressure than females but levels of anxiety and stress were high in female students. According to Vernal, Campbell, \& Beasley (as cited in Irfan and Hussain, 2014) when parents exert pressure on students to achieve higher marks or grades it can lead students towards anxiety and tension. Parents belonging to upper class typically want higher education, excellent grades and respectable jobs for their children. Even at early stage of school, effects of parental pressure are found in their children. Males were facing more pressure than females but levels of anxiety and stress were high in females.

One study from Penn State University (as cited in Irfan and Hussain, 2014) found that out of four twenty one students $19.4 \%$, were seriously thinking to attempt suicide because of high parental pressure for achieving outstanding grades. Females were four times more likely to attempt suicide or a form of self- 
harm. According to Irfan and Hussain (2014), parents pressurize students to achieve outstanding grades and they are facing different levels of anxiety and stress throughout the world. Pakistani students are also being pressurized by their parents to achieve outstanding grades in almost all their subjects. Deb, Strodl \& Sun (2015) conducted a study on Indian high school students regarding academic stress, parental pressure, anxiety and mental health and they concluded that $32.6 \%$ students were facing psychiatric problems therefore policy makers should seriously address this issue. According to this study, nearly two thirds of senior high school students in Kolkata were being affected by academic stress.

The results of Nagpal \& Sinha (2016) study, "perceived parents' pressure and academic achievement among students: exploring the mediating effect of test anxiety among school students" indicated that students' academic achievement decreased due to increased parental pressure, and perceived parental pressure is negatively related to academic achievement. Researches in education and psychology have attempted to study the effects of parental pressure on child, adolescent, and adult behavior, expectations and perceptions for at least 50 years. A large focus of the research has been on how parental pressure may affect children's academic performance. Other areas of child behavior that have been examined in relation to parental influence/pressure include class room behavior, early reading performance, medical career choices, athletic performance and eating disorders. Some of the research also examines parents' reports of their expectations and values. Nowadays there has been an emphasis in research literature examining cross-cultural differences within American subcultures (for example, Asian American, African American, European American,) in parental pressure and academic performance based on surveys of college students (Watson \& Skinner, 2012).

There is a lack of research on how parental influence affects students personality type while students' complete development is the major aim of schooling, therefore studying the factors that affect students' personality and academic achievement is essential, thus, this study tried to investigate the effect of parental influence on students' personality and academic achievement at secondary school level in Islamabad.

\subsection{Research Design}

\section{Research Methodology}

This study was causal comparative in nature. It determined the effect of parental influence on students' personality and academic achievement. This study also compared the gender regarding parental influence and academic achievement. 


\subsection{Population}

Secondary school students studying in class $10^{\text {th }}$ in Islamabad Model schools were the population of present study. Total population was 5,630, in which there were 3,193 female students and 2, 437 male students (Pakistan Education Statistics, 2016).

\subsection{Sample \& Sampling Technique}

Gay (1996) has stated that if population size is 5,000, a sample size of 400 would be enough. Therefore, the sample size was total 400 students studying in class tenth in public sector schools of Islamabad. For the selection of sample, Proportionate stratified sampling technique was used. The total number of male students was 173 , which is $43 \%$ of total sample size (400) because male students were $43 \%$ of total population $(5,630)$, and the total number of female students was 227 , which is $57 \%$ of total sample size (400) because female students were $57 \%$ of total population $(5,630)$. So, the sample size of each group (Male, Female) was proportionate to their total population size.

\subsection{Instrumentation}

Two research instruments were used in this research. For measuring parental influence, an instrument was developed by researcher after considering a subscale of IPI (Inventory of parental Influence) (Campbell, 1994). There were total twenty statements in this instrument. It was five-point Likert scale in which responses were ranging from strongly disagree (S.D) to strongly agree (S.A). For Assessment of personality Big Five Inventory was modified (P \& S, 1999). its forty four items measure the five personality traits which are named as "Extraversion", "Agreeableness", "Conscientiousness", "Neuroticism", and "Openness to experience", on a five point Likert scale in which responses were ranging from one (strongly disagree) to five (strongly agree).

Academic achievement of the students was measured by their marks which they obtained in class $9^{\text {th }}$ annual examination of the Federal Board of Intermediate and Secondary Education (FBISE).

\subsection{Validity \& Reliability of Instruments}

Both instruments were validated through expert opinion. Both instruments were pilot tested before final data collection. The reliability coefficient of instruments was calculated by applying Cronbach's Alpha reliability method and it was .815 for parental influence scale and .769 for Big Five inventory.

\subsection{Data Collection}

Researcher personally visited the sampled schools for data collection and after receiving permission of principals administered the research instruments. 


\section{Data Analysis \& Results}

On the basis of parental influence scores, all subjects of the study were divided in to three groups. The grouping was based on percentile scores. Minimum parental influence score was 23 while maximum parental influence score was 98. Low parental influence group's percentile score was up to 34 and in this group, scores were ranging from 1 to 65 . Moderate parental influence group's percentile score was between 35 and 68, and this group's scores were ranging from 66 to 72 . High parental influence group's percentile score was above 68 and subjects having more than 72 score were part of this group. Data were analyzed through mean scores, one-way ANOVA and t-test. The significance level of 0.05 was used to test the hypotheses.

Table 4.1 Parental influence, Students' personality \& Academic Achievemen

\begin{tabular}{lcccc}
\hline & $\mathrm{N}$ & Minimum & Maximum & Mean \\
\hline $\begin{array}{l}\text { Total parental influence } \\
\text { Valid N (list wise) }\end{array}$ & 400 & 23 & 98 & 67.42 \\
\hline & 400 & & & \\
\hline & $\mathrm{N}$ & Minimum & Maximum & Mean \\
\hline Personality & 400 & 16 & 103 & 54.53 \\
Valid N (list wise) & 400 & & & \\
\hline & & & & \\
\hline & $\mathrm{N}$ & Minimum & Maximum & Mean \\
\hline Academic Achievement & 400 & 146 & 459 & 338.28
\end{tabular}

Valid N (list wise) $\quad 400$

Table \# 4.1 shows that the mean of parental influence score was 67.42 and minimum parental influence score was 23 while maximum parental influence score was 98 . The mean of personality score was 54.53 and minimum personality score was 16 while maximum personality score was 103 and the mean of academic achievement score was 338.28 and minimum academic achievement score was 146 while maximum academic achievement score was 459 . 
Table 4.2 One Way ANOVA results for the Comparison of Students' Personality having High, Low and Moderate Parental Influence

\begin{tabular}{lccccc}
\hline & $\begin{array}{c}\text { Sum of } \\
\text { Squares }\end{array}$ & df & $\begin{array}{c}\text { Mean } \\
\text { Square }\end{array}$ & F & Sig. \\
\hline Between Groups & 800.997 & 2 & 400.498 & 2.278 & .104 \\
Within Groups & 69782.701 & 397 & 175.775 & & \\
Total & 70583.697 & 399 & & & \\
\hline
\end{tabular}

Table \# 4.2 indicates that the $p$ value (.104) was greater than 0.05 and the null hypothesis mentioning that there is no significant difference among the students' personality having high, low and moderate parental influence was accepted. So, no significant difference was found between students' total personality having high, low and moderate parental influence.

Table 4.3 One Way ANOVA results for the Comparison of Extraversion Factor of Students' Personality having High, Low and Moderate Parental Influence

\begin{tabular}{lccccc}
\hline & $\begin{array}{c}\text { Sum of } \\
\text { Squares }\end{array}$ & df & $\begin{array}{c}\text { Mean } \\
\text { Square }\end{array}$ & F & Sig. \\
\hline Between Groups & 6.933 & 2 & 3.466 & .158 & .854 \\
Within Groups & 8735.845 & 397 & 22.005 & & \\
Total & 8742.777 & 399 & & & \\
\hline
\end{tabular}

Table \# 4.3 shows that $p$ value (.854) was more than 0.05 and the null hypothesis mentioning that there is no significant difference among the extraversion factor of students' personality having high, low and moderate parental influence was accepted at 0.05 level of significance. So, there was no significant difference between the extraversion factor of students' personality having high, low and moderate parental influence.

Table 4.4 One Way ANOVA for the Comparison of Agreeableness Factor of Students' Personality having High, Low and Moderate Parental Influence

\begin{tabular}{lccccc}
\hline & $\begin{array}{c}\text { Sum of } \\
\text { Squares }\end{array}$ & df & $\begin{array}{c}\text { Mean } \\
\text { Square }\end{array}$ & F & Sig. \\
\hline Between Groups & 122.625 & 2 & 61.313 & 2.490 & .084 \\
Within Groups & 9777.365 & 397 & 24.628 & & \\
Total & 9899.990 & 399 & & & \\
\hline
\end{tabular}

Table 4.4 shows that $p$ value (.084) was more than 0.05 and the null hypothesis mentioning that there is no significant difference among the 
agreeableness factor of students 'personality having high, low and moderate parental influence was accepted. So, there was no significant difference between the agreeableness factor of students "personality having high, low and moderate parental influence.

Table 4.5 One Way ANOVA for the Comparison of Conscientiousness Factor of Students' Personality having High, Low and Moderate Parental Influence

\begin{tabular}{lccccc}
\hline & $\begin{array}{c}\text { Sum of } \\
\text { Squares }\end{array}$ & df & $\begin{array}{c}\text { Mean } \\
\text { Square }\end{array}$ & F & Sig. \\
\hline Between Groups & 298.917 & 2 & 149.458 & 5.564 & .004 \\
Within Groups & 10664.361 & 397 & 26.862 & & \\
Total & 10963.278 & 399 & & & \\
\hline
\end{tabular}

Table 4.5.1 Results of LSD Post Hoc Test

\begin{tabular}{ccc}
\hline Comparisons & Mean difference & Significance \\
\hline Low versus High & -2.060 & .001 \\
Moderate versus high & -1.506 & .019
\end{tabular}

Table 4.5 results indicate that $p$ value (.004) was less than 0.05 and the null hypothesis stating that there is no significant difference between the conscientiousness factor of students' personality having high, low and moderate parental influence was rejected. So, a significant difference was found between the conscientiousness factor of students' personality having high, low and moderate parental influence. Table \# 4.5.1 shows the results of LSD Post Hoc Test which indicated that students from high parental influence group were more conscientious.

Table 4.6 One Way ANOVA for the Comparison of Neuroticism Factor of Students' Personality having High, Low and Moderate Parental Influence

\begin{tabular}{lccccc}
\hline & $\begin{array}{c}\text { Sum of } \\
\text { Squares }\end{array}$ & df & $\begin{array}{c}\text { Mean } \\
\text { Square }\end{array}$ & F & Sig. \\
\hline Between Groups & 129.786 & 2 & 64.893 & 3.114 & .046 \\
Within Groups & 8274.152 & 397 & 20.842 & & \\
Total & 8403.937 & 399 & & & \\
\hline
\end{tabular}


Table 4.6.1 Results of LSD Post Hoc Test

\begin{tabular}{ccc}
\hline Comparisons & Mean difference & Significance \\
\hline Moderate versus high & 1.389 & .001 \\
\hline
\end{tabular}

Table 4.6 results indicate that the p value (.046) was less than 0.05 and the null hypothesis mentioning that there is no significant difference between the neuroticism factor of students' personality having high, low and moderate parental influence was rejected. So, a significant difference was found between the neuroticism factor of students' personality having high, low and moderate parental influence. Table 4.6.1 shows the results of LSD Post Hoc Test which indicated that students from moderate parental influence group were more neurotic.

Table 4.7 One Way ANOVA for the Comparison of Openness Factor of Students' Personality having High, Low and Moderate Parental Influence

\begin{tabular}{lccccc}
\hline & $\begin{array}{c}\text { Sum of } \\
\text { Squares }\end{array}$ & df & $\begin{array}{c}\text { Mean } \\
\text { Square }\end{array}$ & F & Sig. \\
\hline Between Groups & 39.528 & 2 & 19.764 & .528 & .590 \\
Within Groups & 14855.662 & 397 & 37.420 & & \\
Total & 14895.190 & 399 & & & \\
\hline
\end{tabular}

Table 4.7 shows that $p$ value (.590) was greater than 0.05 and the null hypothesis stating that there is no significant difference between the openness factor of students "personality having high, low and moderate parental influence was accepted. So, no significant difference was found between the openness factor of students 'personality having high, low and moderate parental influence.

Table 4.8 One Way ANOVA for the Comparison of Students' Academic Achievement having High, Low and Moderate Parental Influence

\begin{tabular}{lccccc}
\hline & $\begin{array}{c}\text { Sum of } \\
\text { Squares }\end{array}$ & df & $\begin{array}{c}\text { Mean } \\
\text { Square }\end{array}$ & F & Sig. \\
\hline Between Groups & 38964.412 & 2 & 19482.206 & 4.294 & .014 \\
Within Groups & 1801013 & 397 & 4536.557 & & \\
Total & 1839978 & 399 & & & \\
& & & & &
\end{tabular}

Table 4.8.1 Results of LSD Post Hoc Test

\begin{tabular}{lrr}
\hline Comparisons & Mean difference & Significance \\
\hline Low vs. Moderate & 20.697 & .012 \\
Low vs. High & 20.829 & .012 \\
\hline
\end{tabular}


Table 4.8 shows that $\mathrm{p}$ value (.014) was less than 0.05 and the null hypothesis mentioning that there is no significant difference between students' academic achievement having high, low and moderate parental influence was rejected. So, a significant difference was found between students' academic achievement having high, low and moderate parental influence. Table 4.8.1 shows the results of LSD Post Hoc Test which indicated that students from low parental influence group had better academic achievement and parental influence had a negative effect on students' academic achievement.

Table 4.9 Gender Wise Difference on the Basis of Parental Influence (Summary of "t" test Results)

\begin{tabular}{cccccc}
\hline Gender & $\mathrm{N}$ & Mean & t value & $\mathrm{df}$ & P value \\
\hline Male & 173 & 325.74 & .043 & 398 & .138 \\
Female & 227 & 348.88 & & & \\
\hline
\end{tabular}

Table 4.9 shows that $p$ value (.138) was more than 0.05 and the null hypothesis mentioning that there is no significant difference between male and female students regarding parental influence was accepted. So, no significant difference was found between male and female students on the basis of parental influence.

Table 4.10 Gender Wise Difference in Students' Academic Achievement (Summary of "t" test Results)

\begin{tabular}{cccccc}
\hline Gender & $\mathrm{N}$ & Mean & $\mathrm{t}$ value & $\mathrm{df}$ & $\mathrm{P}$ value \\
\hline Male & 173 & 325.34 & -3.284 & 328.575 & .014 \\
Female & 227 & 348.15 & & & \\
\hline
\end{tabular}

Table 4.10 shows that $p$ value (.014) was less than 0.05 and the null hypothesis stating that there is no significant difference between male and female students' academic achievement was rejected. So, a significant difference was found between the academic achievement of male and female students. The mean score of female students (348.15) was greater than the mean score of male students (325.34). Thus it is obvious from the results that female students' academic performance was better than male students.

Table 4.11 Gender Wise Difference Between Students' Personality (Summary of "t" test Results)

\begin{tabular}{cccccc}
\hline Gender & $\mathrm{N}$ & Mean & $\mathrm{t}$ value & $\mathrm{df}$ & P value \\
\hline Male & 173 & 51.87 & -3.543 & 398 & .135 \\
Female & 227 & 56.56 & & & \\
\hline
\end{tabular}


Table 4.11 shows that $p$ value (.135) was more than 0.05 and the null hypothesis mentioning that there is no significant difference between male and female students' personality was accepted. So, no significant difference was found between male and female students' total personality.

\section{Discussion \& Conclusions}

The present research was aimed to find out the effect of parental influence on students' personality and academic achievement. The findings indicated that parental influence score was ranging from 23 to 98 , the personality score was ranging from 16 to 103 and the academic achievement score was ranging from 146 to 459 . This study revealed that parental influence had a negative effect on students' academic achievement. This result is supported by Nagpal and Sinha (2016). They reported that students' academic achievement decreased due to increased parental pressure, and perceived parental pressure is negatively related to academic achievement. This finding is inconsistent with the findings of Akhtar \& Aziz (2011). They concluded in their study that university students' academic achievement was positively affected by parental pressure.

There was no significant difference between the student's total personality having high, low and moderate parental influence. So, no significant effect of parental influence was found on total personality of students. There was a significant difference between the conscientiousness and neuroticism factors of students' personality having high, low and moderate parental influence while no significant difference was found between the extraversion, agreeableness and openness factors of students' personality having high, low and moderate parental influence. It was concluded that only conscientiousness and neuroticism factor of students' personality were significantly affected by parental influence, so parental influence had partial effect on five factors of students' personality.

No significant difference was found between male and female students on the basis of parental influence. So, there was no significant gender wise difference of parental influence on students. This finding is inconsistent with the findings of Irfan and Hussain (2014). They reported that male students face more pressure than female students but female students had higher levels of anxiety and stress.

There was a significant difference between male and female students' academic achievement. Female students' academic performance was better than male students. This result is supported by Parveen (2007). She found that there was a significant gender wise difference in students' academic achievement and female students 'academic performance was better than male students. No significant difference was found between male and female students' total personality. This finding is inconsistent with the findings of Parveen (2007). She 
concluded in her study that a significant gender wise difference was found in student's achievement and their total personality.

Although there was significant effect of parental influence on students' academic achievement and conscientiousness and neuroticism factor of their personality but no significant effect of parental influence was found on students' total personality and extraversion, agreeableness and openness factor of their personality. Therefore, it was concluded that parental influence had significant effect on students' academic achievement, partial effect on five factors of students' personality, and no significant effect on students' total personality. There was a significant gender wise difference in students' academic achievement but no significant gender wise difference of parental influence was found on students, and no significant gender wise difference was found in students' total personality.

\section{Recommendations}

1. The conclusions indicated that parental influence had significant effect on conscientiousness and neuroticism factors of students' personality while no significant effect of parental influence was found on student's total personality and extraversion, agreeableness and openness factors of students' personality. Students from high parental influence group were found to be more conscientious and students from moderate parental influence group were found to be more neurotic. So for the proper development of a child's personality, parents may play an important role by managing their influence.

2. Results of this study indicated that reduced parental influence is important for student's improved academic achievement, so parents may help their children to improve academic performance by reducing their influence and by giving them positive feedback about their educational matters.

3. The conclusions showed that female students' academic performance was better than male students, so efforts could be made to improve the academic performance of male students. For instance, teachers may give more attention, encouragement and support to male students for improving their performance. Teachers can establish healthy competitive environment in class room by dividing students in to three or four groups; it will motivate male students to improve their performance.

4. The educational institutions may arrange some workshops and meetings with parents to provide awareness about parental influence.

5. Parents and teachers may work together to recognize the amount of parental influence which is necessary for improved academic performance and proper development of students' personality. For this purpose, Educational institutions may arrange parent teacher meetings regularly. 


\section{References}

Akhtar, Z., \& Aziz, S. (2011). The Effect of Peer and Parent Pressure on the Academic Achievement of University Students. Language in India Strength for Today and Bright Hope for Tomorrow, 11, 1930-2940.

Campbell, J. R. (1994). Developing cross-cultural/cross-national instruments: Using cross-national methods and procedures. International Journal of Educational Research, 21, 675-684.

Deb, S., Strodl, E., \& Sun, J. (2015). Academic Stress, Parental Pressure, Anxiety and Mental Health among Indian High School Students. International Journal of Psychology and Behavioral Sciences, 5(1), 26-34.

Gay, L. R. (1996). Educational research: Competencies for analysis and application. Beverly Hill, CA: Sage Publications.

Irfan, S., \& Hussain, N. (2014). Parental pressure on student's attainment of high grades in Karachi based Universities. Pakistan Business Review, 16, 156176.

John, O. P., \& Srivastava, S. (1999). The Big-Five trait taxonomy: History, measurement, and theoretical perspectives. Handbook of personality: Theory and research, 2, 102-138.

Nagpal, M., \& Sinha, C. (2016). Perceived parental pressure and academic achievement among students: Exploring the mediating effect of test anxiety among school students. Open Journal Of Educational Psychology, 13-20.

Pakistan Education statistics 2014-2015. (2016). Retrieved from AEPAM online library:

http://library.aepam.edu.pk/Books/Pakistan\%20Education\%20Statistics \%202014-15.pdf

Parveen, A. (2007). Effect of Home Environment on Personality and Academic Achievement of Students of Grade 12 in Rawalpindi Division. Retrieved from 
http://citeseerx.ist.psu.edu/viewdoc/download?doi=10.1.1.474.1140\&rep $=$ rep $1 \&$ type $=$ pdf

Quach, A., Epstein, N., Riley, P., Falconier, M., \& Fang, X. (2013). Effects of Parental Warmth and Academic Pressure on Anxiety and Depression Symptoms in Chinese Adolescents. Journal of Child and Family Studies, 24(1), 106-116.

Shazia, S. (2014). Self-concept, learning styles, study habits and academic achievement of adolescents in Kashmir: A study on psychological variables and academic achievement of adolescents in Kashmir (1st ed.). Hamburg: Anchor Academic Publishing.

Watson, T., \& Skinner, C. (2012). Encyclopedia of school psychology (1st ed.). New York: Springer Science \& Business Media. 